\title{
Robbin C. Moran, Fern and Lycophyte Curator- an Appreciation
}

\author{
Alejandra Vasco ${ }^{1,4}$ (D) Fernando B. Matos $^{2}$ (D) $\cdot$ Michael A. Sundue ${ }^{3}$ \\ ${ }^{1}$ Botanical Research Institute of Texas, 1700 University Drive, Fort Worth, TX 76107, USA \\ ${ }^{2}$ Departamento de Biologia Vegetal, Universidade Federal de Viçosa, Av. Purdue s.n., Viçosa, Minas \\ Gerais CEP 36570-900, Brazil; e-mail: fbittmatos@gmail.com \\ ${ }^{3}$ Department of Plant Biology, The Pringle Herbarium, University of Vermont, 111 Jeffords Hall, \\ Burlington 05405 VT, USA; e-mail: sundue@gmail.com \\ ${ }^{4}$ Author for Correspondence; e-mail: avascog@gmail.com \\ Published online: 29 June 2021 \\ (C) The New York Botanical Garden 2021
}

\begin{abstract}
To mark the commencement of his retirement as Nathaniel Lord Britton Curator of Botany, and appointment as Curator Emeritus at the New York Botanical Garden, we pay tribute to Robbin Moran and impact on the botanical community with a brief synopsis of his career. Naturalist, fern expert, adored teacher-it is difficult to adequately pay tribute to his accomplishments, and his impact on botany in a single article. Robbin has published four books, 13 monographs of neotropical fern clades, over 170 scientific papers, and dozens of popular articles. He has named 115 new species, five new genera, and one family of ferns. He is eponymized by seven new species and the genus Moranopteris. We recount his earliest days and academic trajectory to become a leading researcher and educator in pteridology. We highlight his major influences, scientific accomplishments, and outreach to the botanical community.
\end{abstract}

Keywords Biography $\cdot$ Botany, Curator $\cdot$ Pteridology $\cdot$ Robbin Craig Moran

Alejandra Vasco

avascog@gmail.com

Fernando B. Matos

fbittmatos@gmail.com

Michael A. Sundue

sundue@gmail.com

1 Botanical Research Institute of Texas, 1700 University Drive, Fort Worth, TX 76107, USA

2 Departamento de Biologia Vegetal, Universidade Federal de Viçosa, Av. Purdue s.n., Viçosa, Minas Gerais CEP 36570-900, Brazil

3 Department of Plant Biology, The Pringle Herbarium, University of Vermont, 111 Jeffords Hall, Burlington 05405 VT, USA 


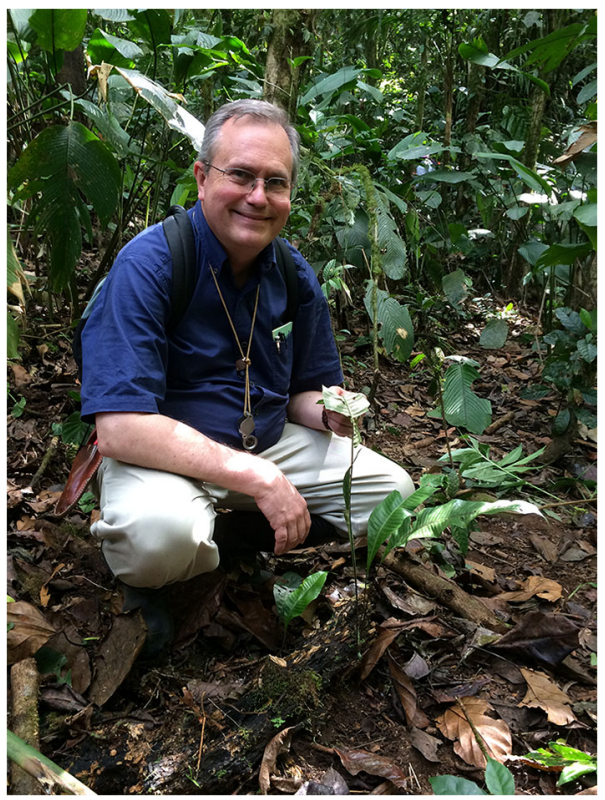

Fig. 1 Robbin Moran holding Campyloneurum concavum R.C. Moran \& Labiak, at Las Cruces Biological Station. Costa Rica, 2019. Photo by Alejandra Vasco

For: The Botanical Review

In August 2020, Robbin Craig Moran retired from The New York Botanical Garden (NYBG), where he had worked for 23 years. He had held the title of Nathaniel Lord Britton Curator of Botany, and now, in retirement, is Curator Emeritus (Fig. 1). Naturalist, fern expert, adored teacher-it is difficult to adequately pay tribute to his accomplishments, and his impact on botany in a single article. Robbin has published four books, 13 monographs of neotropical fern clades, over 170 scientific papers, and dozens of popular articles. He has named 115 new species, five new genera, and one new family of ferns. He is eponymized by seven new species and the genus Moranopteris. He mentored three doctoral students and has taught hundreds of students eager to learn the biology and taxonomy of ferns. With these accomplishments, Robbin's contributions to pteridology will be acknowledged for decades to come. And, while we are sure Robbin is by no means done with research, we want here to celebrate his contributions and mark the occasion of his retirement. This piece is a voyage through Robbin's life and a personal reflection on it by us, his former graduate students (Fig. 2a). If you don't love ferns, it's only because you've never had a chance to speak with Robbin. So Robbin with that, we salute you. Buen Helecho! 

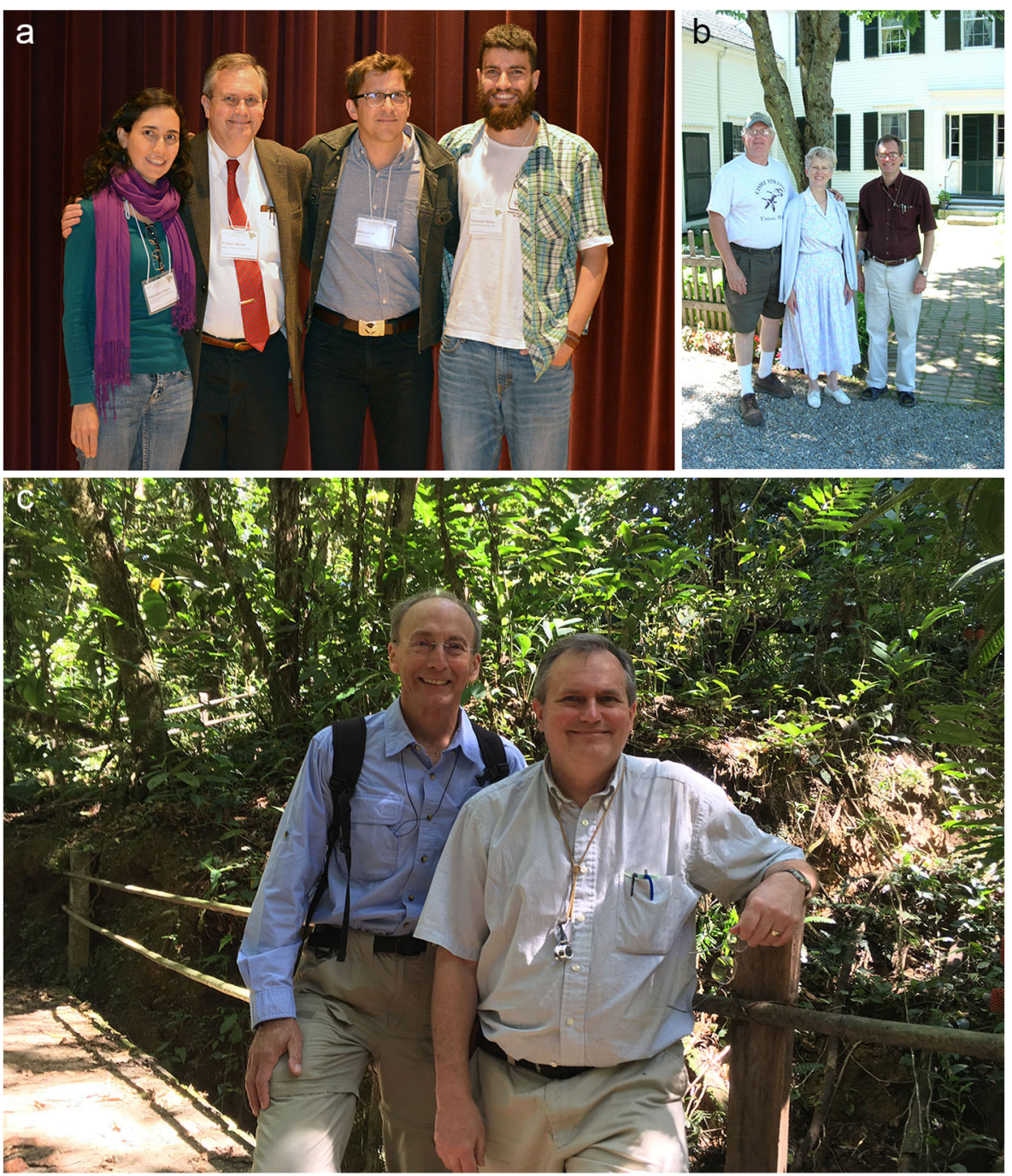

Fig. 2 a. Robbin Moran (second from left to right) with his three graduate students (left to right): Alejandra Vasco, Michael Sundue, and Fernando Matos. Next Generation Pteridology Symposium. Washington, DC, USA, 2015. Photo by Eddie Watkins. b. Robbin Moran (right) and his biology high school teacher Dr. David Shaub and wife Susan Shaub (left and middle). Union, Maine, 2005. Photo by Alejandra Vasco. c. Robbin Moran (right) and Carl Taylor (left), at Las Cruces Biological Station. Costa Rica, 2017. Photo by Alejandra Vasco

\section{A Brief Timeline of Robbin's Life}

\section{Early Biography}

Robbin C. Moran was born in 1956 in Illinois, and grew up in the village of Lake Bluff, a small town about 30 miles north of downtown Chicago. His parents: Livia Moran, a secretary at the local high school, and John Howard Moran, a self-employed art restorationist, were not particularly interested in science, but they were tolerant of 
Robbin's many interests in the subject. His first love in science was astronomy. As an enthusiastic teenager, he ground his own telescope mirror in his basement and had it aluminized at the Adler Planetarium in Chicago. In high school, however, he realized he would never be an astronomer because he was weak in math and physics. Instead, he gravitated toward biology.

Throughout his youth, Robbin pursued insects and butterflies, and he grew up exploring the woods and ravines near his home. The diverse spring flora of those areas ignited Robbin's interest in plants, and later he would publish floristic accounts about them (Bushey \& Moran, 1978; Moran, 1980). During his sophomore year at Lake Forest High School, his biology teacher, Dr. David Shaub, required students to prepare and identify 50 herbarium specimens (Fig. 2b). Collecting and identifying these plants was a formative experience, piquing Robbin's interest in the local flora. Following this, he found a summer job during senior year in high school, as a naturalist at the Ryerson Conservation Area in Deerfield, Illinois, where he prepared a herbarium of wildflowers for the nature preserve.

His interest in plant systematics only came to a head when Robbin tested his parents' patience by purchasing a copy of the 3-volume set of the New Britton \& Brown's Illustrated Flora of the Northeastern United States and Adjacent Canada, as revised by Henry A. Gleason and published by NYBG (Gleason, 1952), for $\$ 75.00$ dollars!! A small fortune for a senior high schooler back in 1974. Robbin loved the books and learned a great deal from them. Nathaniel Lord Britton and Henry A. Gleason were Robbin's botanical heroes. Nevertheless, his parents were aghast that he would spend that much money on botany books instead of saving for college tuition. Twenty-four years later in 1998, Robbin became a curator at NYBG, eventually holding the title of his botanical hero as the Nathaniel Lord Britton Curator of Botany.

\section{College Years}

After graduating from high school, Robbin attended Beloit College in Wisconsin, where he majored in biology. During summers, he continued his involvement with botany, working as a field botanist for the Illinois Natural Areas Inventory, a project that inventoried remaining pre-settlement natural areas left in the state. His interest in the flora and vegetation of southern Illinois continued, and after earning his B.S. in biology in 1978, Robbin began a M.S. program at Southern Illinois University at Carbondale, where he studied under Dr. Robert H. Mohlenbrock. For his thesis, he reconstructed the pre-settlement vegetation of three counties in northeastern Illinois from the early (1830s) Government Land Office surveys (Moran, 1978a, b).

While working toward his Master's degree, Robbin was employed during the summers by the Wisconsin Scientific Areas Preservation Council, a part of the Wisconsin Department of Natural Resources (WDNR). The job brought Robbin into contact with Dr. Carl Taylor from the Milwaukee Public Museum. Carl went to Madison, to give field botanists in the Scientific Areas section a crash-course on the identification of Wisconsin ferns and lycophytes. Immediately, Robbin fell in love with ferns. Hearing Carl talking about Dryopteris in northern Wisconsin, Robbin became interested in hybridization and polyploidy as major modes of evolution for these plants. 
Robbin credits Carl, more than anyone, with getting him interested in ferns and lycophytes (Fig. 2c).

After Carl Taylor's fern course, Robbin paid more attention to ferns in the field and connected with other people studying ferns in the US. He met Dr. James Peck, who was then at the University of Wisconsin at La Crosse, at the Pigeon Lake Biological Station in northwestern Wisconsin, where Robbin was stationed for his work with the Wisconsin DNR. In the summer of 1980, Robbin attended a one-month fern course with legendary University of Michigan, Ann Arbor, fern experts Drs. Florence S. and Warren H. (Herb) Wagner at the Flathead Lake Biological Station in northwestern Montana. Earlier that year, Robbin had discovered a naturally occurring, undescribed hybrid between Asplenium trichomanes L. and A. (Camptosorus) rhizophyllum L. Florence and Herb taught him how to count chromosomes so that he could analyze chromosome pairing behavior of the new hybrid. The study resulted in Robbin's first paper about ferns, "× Asplenosorus shawneensis, a new natural fern hybrid between Asplenium trichomanes and Camptosorus rhizophyllus" (Moran, 1981). Most important, Herb left an unmistakable impression on Robbin. Robbin wrote a one-page piece about the unforgettable experience of Meeting Herb Wagner for the first time in Farrar (2002). Herb later served as a member on Robbin's PhD committee.

\section{Graduate Work}

In 1981, Robbin started his $\mathrm{PhD}$ at the University of Illinois at Urbana-Champaign under the advisership of Dr. Kenneth Robertson. This was the beginning of his long relationship with ferns of the American tropics. For his doctoral thesis he monographed the neotropical genus Polybotrya (Dryopteridaceae) (Moran, 1987a). He picked a tropical genus, because, as he said, "to really understand ferns, one must go to the tropics, where most of the species and taxonomic groups occur." He received an NSF Doctoral Dissertation Improvement Grant that allowed him to spend four weeks at Harvard University studying with Drs. Rolla and Alice Tryon, the other preeminent fern experts. Thus, Robbin became the only graduate student to work with both the Tryons and the Wagners, research groups that had become antagonistic.

His NSF fellowship and a small grant from the Tinker Foundation allowed Robbin to conduct field work in Costa Rica. This 1982 trip was his first exposure to the tropics, and he was hooked! Costa Rican fern-specialist Luis Diego Gómez, then working at the Museo Nacional de Costa Rica, hosted Robbin in his house in San José, and provided him with an introduction to tropical ferns. Luis Diego's mentorship was critical, since at that time, the only books available to identify ferns and lycophytes in the neotropics were Stolze's Ferns and Fern Allies of Guatemala (Stolze, 1976, 1981, 1983), Alan Smith's Pteridophytes of Chiapas, Mexico (Smith, 1981), and five 3-ring notebooks containing photocopied keys from David Lellinger's manuscript for the Ferns and Fern Allies of Costa Rica, Panama, and the Chocó (only the first part was published (Lellinger, 1989), not the second). There were few monographs for neotropical ferns back then, something Robbin would spend the rest of his career correcting. Acknowledgment of his friendship with Luis Diego was later immortalized in the species Polybotrya gomezii R. C. Moran, an endemic species from Costa Rica, dedicated to him (Moran, 1987a). 


\section{Early Career}

After completing his Ph.D. on Polybotrya in 1986, Robbin worked as a postdoctoral researcher on the Flora Mesoamericana project at the Missouri Botanical Garden (MO). When the postdoc ended after two years, he was hired as an Assistant Curator for another five years. These were exciting times at MO, which was one of the most active and the fastest growing herbaria in the world, employing dozens of botanists, and rapidly publishing major floristic works. The fern volume of Flora Mesoamericana was a large project and it would eventually treat nearly 1400 species, or about $10 \%$ of the world's fern flora (Moran \& Riba, 1995). During nearly seven years at MO, Robbin wrote taxonomic treatments for several groups of ferns, edited the whole volume, identified thousands of specimens, and published many new species (Moran, 1990a; b; c, 1991a, 1992). Written in Spanish, the fern volume of Flora Mesoamericana remains a primary reference for the region and the neotropics.

While working at MO in 1988, Robbin met his wife-to-be Cirri (née Rohrbach), a St. Louis native, who was working as an assistant to Dr. Gerrit Davidse, one of the editors for Flora Mesoamericana. Cirri and Robbin got married on 11 May 1991 in Tower Grove Park, just south of MO. Fellow pteridologist Alan R. Smith was the best man (Fig. 3a). For the wedding, Robbin and Cirri had asked a local florist to make a bouquet consisting of ferns. The florist used six fern species, one of which could not be identified to genus by any of the six pteridologists who attended the wedding, not even to genus! After the wedding, Robbin went straight to the florist shop and asked to see more of the plant. When the florist brought out the fern, it was obvious what it was -a species of forked fern belonging to the tropical genus Sticherus (Gleicheniaceae). No one had been able to identify it because only the apical portions of the pinnae, which are not particularly diagnostic, had been used in the bouquet.

Robbin's dedicated taxonomic work attracted the attention of Dr. Benjamin Øllgaard of Aarhus University (AAU) in Denmark. In 1993, he offered Robbin a three-year guest lecturer (Gaestlektur) position in the Department of Systematic Botany. At this time, Benjamin was a lead organizer for the fern and lycophyte treatments for the Flora of Ecuador, and Robbin's move to Aarhus engendered a number of new collaborations and projects on Ecuadorian ferns, resulting in several new species and floristic treatments for the Flora of Ecuador series (Moran, 1995; Moran \& Øllgaard, 1995, 1998; León \& Moran, 1996). While at Aarhus, Robbin also collaborated with Dr. Hannah Tuomisto, a fern ecologist and systematist at the University of Turku in Finland, on the edaphic distribution of ferns in Amazonian Ecuador (Tuomisto et al., 1998; Tuomisto \& Moran, 2001; Tuomisto et al., 2002, 2003).

\section{The New York Years}

After Aarhus, Robbin returned to the United States as an Associate Professor at the University of Arkansas at Little Rock. There he worked with his colleague James Peck, who he had met during his Wisconsin days. About one year later, Dr. John Mickel, curator of ferns at NYBG, invited Robbin to apply for a position and continue John's curatorship of one of the largest fern collections in the United States. To accomplish this, John Mickel negotiated an early retirement, enabling Robbin to become an Associate Curator. This was the beginning of Robbin's 23 years at NYBG. 

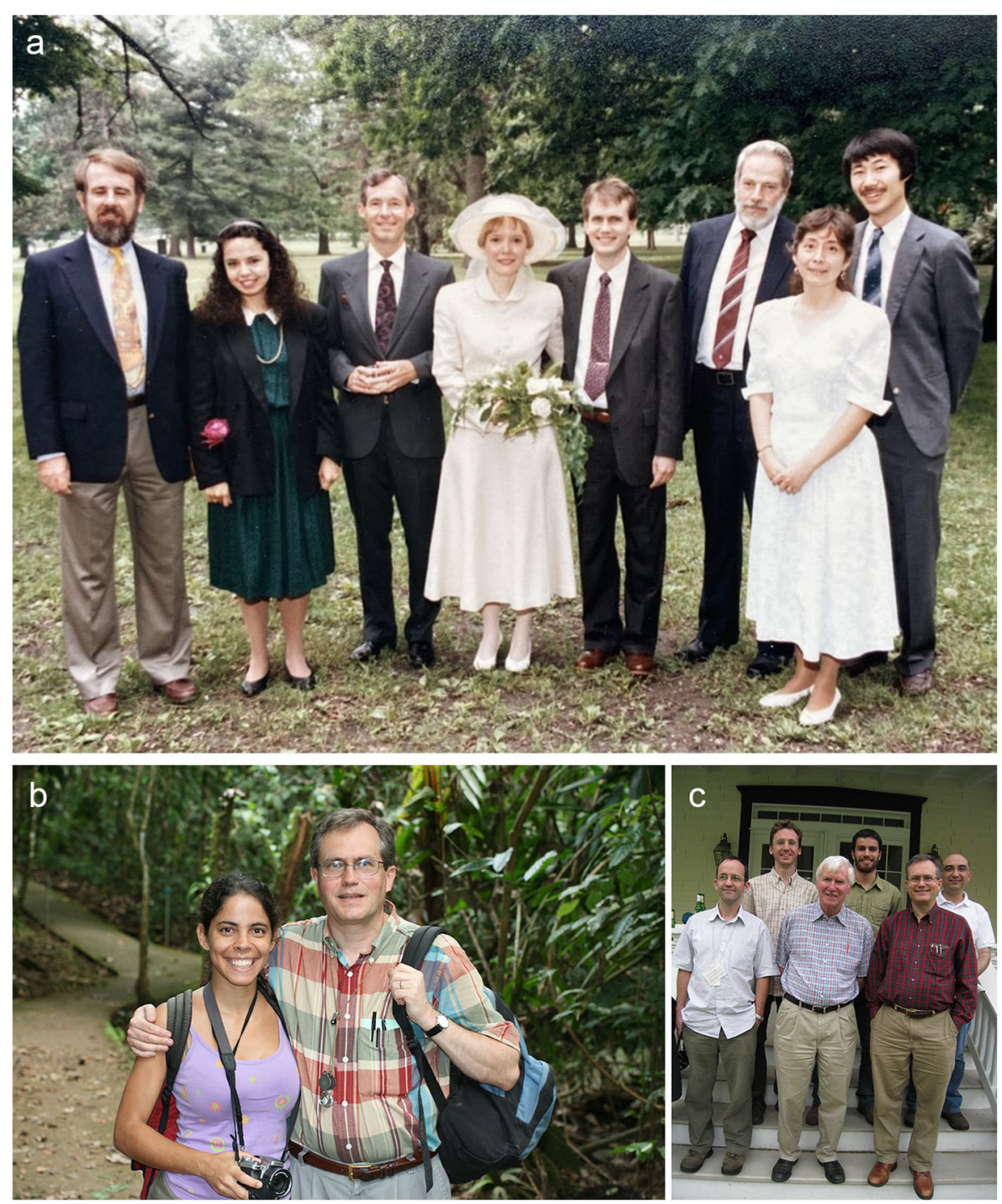

Fig. 3 a. Pteridologists at Cirri and Robbin Moran wedding from left to right: Henk van der Werff, Mónica Palacios Rios, Alan Smith, Cirri Moran, Robbin Moran, Robert Stolze, Blanca León, and Noriaki Murakami. Saint Louis, Missouri, 1991. Photographer unknown. b. Robbin Moran (left) with then grad student and coadvisee Josmaily Lóriga (right), at La Selva Biological Station during the Tropical Ferns and Lycophytes course. Costa Rica, 2008. Photo by Alejandra Vasco. c. Robbin Moran and several of his long-term collaborators during his time at the New York Botanical Garden. From left to right, top row: Germinal Rouhan, Fernando Matos, Jefferson Prado; bottom row: Paulo Labiak, John Mickel, Robbin Moran. New York, 2008. Photo by Carol Mickel

While at NYBG, Robbin was a dedicated herbarium curator, maintaining the collection at the William and Linda Steere Herbarium (NY) as a critical resource for people working with neotropical ferns. Visiting NY became a goal for many graduate students and fern curators from all over the world focusing on neotropical ferns. Despite his busy schedule, Robbin always found time for visitors, helping them navigate the more than 200,000 fern specimen 
collection, and also to share stories over a cafecito (the word for a "little coffee" that Robbin will always say in Spanish, no matter the mother language of the visitor).

At NYBG, Robbin collaborated with many US and international fern researchers, had four National Science Foundation grants, and advised three PhD students through the City University of New York (CUNY) and the NYBG joint Graduate Studies Program. He also co-advised five PhD students based at other institutions in the US (Dr. Thereis Choo), Mexico (Dr. Leticia Pacheco), Brazil (Dr. Paulo Labiak), Germany (Dr. Josmaily Lóriga), and France (Dr. Germinal Rouhan) (Figs. 3b,c).

Robbin's research on ferns flourished at NYBG. He wrote two Books -Fern Grower's Manual (Hoshizaki \& Moran, 2001) and A Natural History of Ferns (Moran, 2004)) _ and many scientific and popular articles. As impactful as Robbin's scientific contributions, was also his community outreach. He taught many graduate courses, both in the US and in the neotropics, was the President of the New York Fern Society for 22 years, and was a regular instructor at various Adult Education classes offered by NYBG. In 2011 he was awarded the American Society of Plant Taxonomy's Peter Raven award for exceptional outreach by a plant systematist (Miller \& Vasco, 2012), and in 2015 he was invited as a keynote speaker for the Next Generation Pteridology Symposium, an International conference on fern and lycophyte research in Washington, DC, USA.

\section{Quintessential Monographer - Marching through the Dryopteridaceae}

Robbin authored or co-authored 13 taxonomic monographs, many of which are from clades and genera of the family Dryopteridaceae, one of the largest families of ferns. His march through the family began with his $\mathrm{PhD}$ thesis. In this monograph Robbin recognized and treated 35 species in Polybotrya, a genus that had not been previously revised and which included many nomenclatural and identification problems (Moran, 1987a). With rigorous detailed and clear descriptions and discussions, ample specimens examined, an easy to use key, spore images, chromosomes squashes, distribution maps, and many illustrations all made by Robbin, this became the standard by which a modern fern treatment would be compared.

Latter Robbin authored or co-authored 10 other monographs of clades within the Dryopteridaceae treating over 200 species. These include Stigmatopteris with 23 species (Moran, 1991b), Lomariopsis with 15 species (Moran, 2000), Triplophyllum with nine species (Prado \& Moran, 2008), the neglected genus Megalastrum with 90 species (Moran \& Labiak, 2009; Moran et al., 2009; Moran \& Prado, 2010; Sundue et al., 2010; Rouhan \& Moran, 2011; Moran et al., 2014a; b), the new genus Mickelia with 10 species (Moran et al., 2010a), Polystichopsis with seven species (Prado \& Moran, 2016), and four separate groups of Elaphoglossum: Elaphoglossum ciliatum group with nine species (Vasco et al., 2009), E. sect. Squamipedia with 17 species (Vasco et al., 2013a), E. decursivum group with seven species (Matos et al., 2019), and E. subsect. Apoda with 14 species (Matos et al., in press).

Besides these monographs, Robbin co-authored others for species-rich groups of neotropical ferns such as Asplenium sect. Hymenasplenium and the genus Callipteris (=Diplazium) (Murakami \& Moran, 1993; Pacheco \& Moran, 1999). These works facilitated the completion of floristic treatments in various neotropical regions, 
particularly Venezuela (Moran, 1987b), Peru (Moran, 1991c), the Guianas (Moran, 1993), Mesoamerica (Moran \& Riba, 1995), and Bolivia (Kessler et al., 2018).

\section{Other Scientific Contributions}

Robbin has also worked on phylogenetics and on inference of ancestral states. His questions have been, what characters diagnose large clades of ferns, and how have morphological traits evolved in the light of inferred phylogenetic relationships? Frankly, thereis no better person to answer these questions because Robbin has spent the previous 25 years accumulating a vast knowledge of esoteric morphological and anatomical characteristics about the world's ferns. Many of his studies have been conducted with the help of long-time collaborators Dr. Paulo Labiak of the University of Parana in Brazil and Dr. Germinal Rouhan of the Muséum National d'Histoire Naturelle in Paris (Fig. 3c). Prominent among these are the first phylogenies of the highly diverse genus Elaphoglossum (Rouhan et al., 2004; Skog et al., 2004), the phylogeny and character evolution in bolbitidoid ferns (Moran et al., 2010; Moran et al., 2010b), perispore morphology in relation to phylogeny of: Elaphoglossum (Moran et al., 2007), the bolbitidoid ferns (Moran et al., 2010), and the Blechnaceae (Moran et al., 2018), the first fossil of Elaphoglossum (Lóriga et al., 2014a), and phylogeny and character evolution in the Neotropical fern genus Stigmatopteris (Moran \& Labiak, 2016).

During his 23 years at NYBG, Robbin also spent time elucidating unknown aspects of fern biology and evolution. This included discovering a previously unknown phenomenon that he and co-authors called "cryptochlorophylly" in which fern spores that appear non-green actually contain chlorophyll (Sundue et al., 2011), using molecular markers to identify a mysterious fern gametophyte (Li et al., 2009), and identifying new instances of nest-forming habits in ferns that trap and decompose leaf-litter (Moran et al., 2018). While at NYBG, Robbin also collaborated with Dr. Barbara Ambrose, an evolutionary developmental botanist, and Dr. Alejandra Vasco, his former doctoral student and then-postdoc. The three studied evolutionary development in ferns. Evolutionary developmental studies in ferns are particularly challenging, because ferns have fewer genetic tools available when compared to angiosperms, but their efforts paid off by providing previously unknown insights into fern leaf development and evolution (Vasco et al., 2013b, 2015, 2016; Ambrose \& Vasco, 2016; Vasco \& Ambrose, 2020).

As a result of his monographic studies, Robbin got interested in botanical nomenclature. In this he specially has collaborated with Dr. Jefferson Prado of the Instituto de Botânica in Sāo Paulo, Brazil, who served as member of the Editorial Committee of the International Code of Nomenclature for Algae, Fungi, and Plants (Fig. 3c). They have proposed adding the terms "Isolectotype", "Isoneotype", and "Isoepitype" (Prado et al., 2010), and other modifications to the Vienna Code (Prado \& Moran, 2010), the Melbourne Code (Prado \& Moran, 2014; Matos et al., 2015; Prado et al., 2015), and most recently the Shenzhen Code (Moran et al., 2020; Prado et al., 2020). 

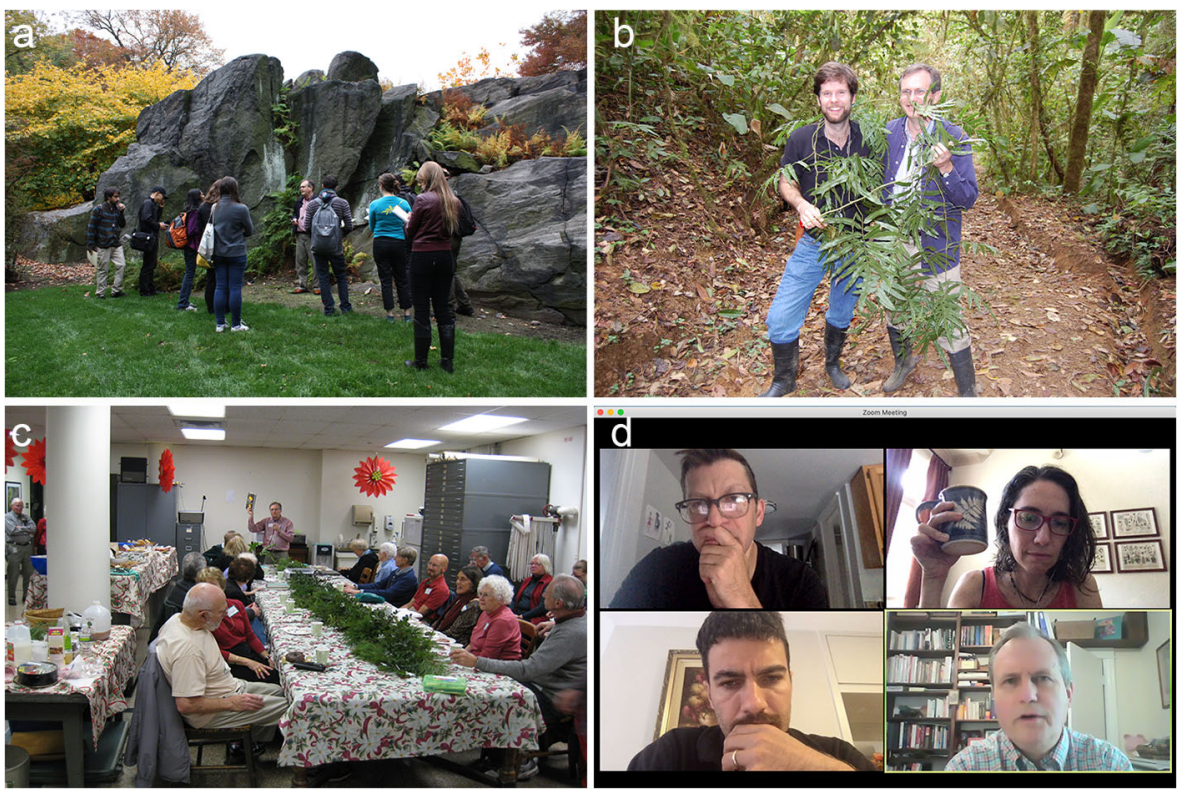

Fig. 4 a. Robbin Moran teaching at the grounds of the New York Botanical Garden. Bronx, NY 2012. Photo by Fernando Matos. b. Robbin Moran (right) and his long-time student, friend, and collaborator Eddie Watkins (left) holding the fern Salpichlaena papyrus G.G. Cárdenas, Tuomisto \& Lehtonen, at La Selva Biological Station during the OTS Tropical Ferns and Lycophytes course. Costa Rica, 2008. Photographer unknown. c. Robbin Moran entertaining the members of the New York Fern Society in the Museum Building, at the New York Botanical Garden. Bronx, NY, Christmas party 2012. Photo by Fernando Matos. d. Robbin Moran (bottom right) and the three authors of this article (left to right, upper row: Michael Sundue, Alejandra Vasco; bottom row: Fernando Matos) meeting online and discussing new ideas on fern evolution during the COVID-19 pandemic. June 2020

\section{Patient Teacher with Plenty of Puns}

Besides research, Robbin is a dedicated teacher always willing to share his encyclopedic knowledge about plants and botanical puns. No matter who is listening, he would always have something interesting and amusing to say. He could take the most ubiquitous local fern, point out a fairly obvious feature, and have his students completely mesmerized (Fig. 4a). This remains true, even for us, his former PhD students. For example, he could ask "say, did I ever show you the anastomosing veins on Onoclea sensibilis?" Despite the answer being "yes, only about 12 times," we remain enchanted by his questions and demonstrations, because Robbin has a way of making the observation important and bringing the plant to life. After all, Robbin is a fern indusiast, and every new fern a sight for sori.

Since the early 1990s, Robbin has taught short (one- or two-week) fern courses in Spanish throughout Latin America (Bolivia, Costa Rica, Venezuela, Ecuador). For these courses, he compiled a bilingual English-Spanish guide to the neotropical fern and lycophyte genera that the students could easily use. His guide has become a hot commodity among pteridologists who regularly trade the latest pdf version among themselves. This is one of the few comprehensive guides to the diversity of neotropical 
ferns written in Spanish. We hope in retirement Robbin will finally find the time to publish an official version of the guide, botanical humor included!

One of the most important activities in Robbin's career has been teaching field courses in Costa Rica for the Organization for Tropical Studies (OTS). In 1998, he first taught Tropical Plant Systematics, which became one of the premier training programs in neotropical plant systematics. Robbin co-taught the course mainly with Dr. Brad Boyle, who was then at the University of Arizona. They taught the course in English during the even-numbered years, and in 2001 they started a Spanishlanguage version of the course that is now taught during the odd-numbered years. Robbin has co-taught the Spanish course mostly with Dr. José Mauricio Bonifacino (Universidad de la República, Uruguay).

For students and teachers, these are memorable field courses, full of perplexing plants, fieldwork, gallo pinto, botany movies, and salsa dancing. Class projects conducted by students in these courses also resulted in several publications, including the first report of the hybrid Adiantum $\times$ variopinnatum Jermy \& T.G. Walker outside of the island Trinidad (Moran \& Watkins, 2002), a new hybrid in Lomariopsis (Moran \& Watkins, 2004), the realization that the filmy fern Trichomanes godmanii Hook. only occurs on the trunks of Welfia palms (Moran \& Russell, 2004), that the root mantles of tree fern trunks harbor more fern epiphytes than angiosperm trunks of the same diameter (Moran et al., 2003), and the first careful documentation of primary hemiepiphytism in ferns (Nitta \& Epps, 2009; Lagomarsino et al., 2012). The latter in particular has led to many further discoveries in fern habits and has promoted discussion about the evolution of habits in ferns (Moran et al., 2010b; Lóriga et al., 2014b; Testo \& Sundue, 2014; Fawcett \& Sundue, 2016; Labiak et al., 2017; Matos et al., 2018; Watts et al., 2019).

In 2008, Robbin and Dr. Eddie Watkins (Colgate University) resurrected the OTS Tropical Ferns and Lycophytes course (Fig. 4b). It had not been taught since 1967 when it was run by John Mickel and Herb Wagner in the early days of OTS. The twoweeks course accepts 15-20 students and includes two invited professors (an all-star team that has already included Drs. Alejandra Vasco, Carl and Jerry Taylor, Donald Farrar, Emily Sessa, Jacob Schneller, Jarmila Pittermann, Kathleen Pryer, Michael Sundue, Michael Windham, and Weston Testo). Many students who have taken this course have gone on to become leading pteridologists. These coursesare always bursting at the seams with new pteridological insight, and so far have led to publications describing fern gametophytes (Canestraro et al., 2014; Choo et al., 2014; Watkins \& Moran, 2019) and novel ways of depicting the fern life-cycle (Haufler et al., 2016).

Back in the temperate zones, Robbinis also busy teaching. He served as an adjunct professor at the City University of New York, teaching pteridology at NYBG (Fig. 4a). Since 2005, he has offered summer field courses at the Eagle Hill Institute, in coastal Maine. His fern course in Maine, is co-organized with Carl Taylor, who first sparked Robbin's interest in ferns back in the late 70's. Because temperate zones have less fern and lycophyte species than tropical zones, this course has allowed Robbin to delve into the natural history and distinct biology of ferns and lycophytes. However, since there are only about 12 species of ferns in the entire state of Maine, it is pretty clear to us that Robbin only teaches there for the lobster dinners and huckleberry pies. 


\section{Community Outreach}

Outside of academia, Robbin has interpreted ferns for the general public. For 22 years, he served as president of the New York Fern Society. This eclectic group of people met on the first Saturday of every month, from October to May, in the Museum Building, at NYBG. During the summer months, field trips were organized in the greater New York area. Robbin and John Mickel acted as the masters of ceremonies of these meetings for many years, captivating the audience with natural history stories and their ferntastic repertoire of puns. Despite the often esoteric subject, these meetings were usually attended by 30-50 people, including New Yorkers from all walks of life (Fig. 4c). During what was perhaps the heyday of these meetings, in 2000, John Mickel and Robbin led two back-to-back field trips to Oaxaca, Mexico. The field trips were for the public and raised money for John and Robbin's research. A member of the fern society, Oliver Sacks (1933-2015), a neurologist and bestselling author went on the first trip and wrote a book, Oaxaca Journal, about the experience (Sacks, 2002). Oliver was a good friend of Robbin and also wrote the foreword for Robbin's book A Natural History of Ferns (Moran, 2004). Robbin paid tribute to Oliver in an article published at the Fiddlehead Forum, the newsletter of the American Fern Society (Moran, 2015).

This book, A Natural History of Ferns, is one of Robbin's most important contributions to public outreach. It gives an entertaining and informative look at why ferns and lycophytes are unique among plants and what these plants are doing in the wild. Amazingly, every single chapter of this book ends with a corny Robbin joke. In 2005, Robbin received for this book, the Silver Award for Best Writing, from the Garden Writer's Association. Since then, the book has been translated into Korean and Portuguese. To quote Oliver Sacks: "A Natural History of Ferns not only represents science writing at its best, but it is a delightful adventure into the world of one of our foremost botanists; it is stimulating, enthralling, a beautiful companion for any fern lover.”

\section{To Many More Years of Frond Memories}

While this tribute takes a look backward, we know that in retirement, Robbin is busy looking forward to new pteridological projects. If his behavior in quarantine during the ongoing COVID-19 lockdown is any indication, we should expect a flurry of new ideas to emerge. During these past ten months Robbin has arranged a regular video discussion group focused entirely on new insights into the biology and evolution of ferns (Fig. 4d). That sounds reasonable, but actually many of these conversations have revolved around Robbin's fascination and observations about fern aerophores and their relation to the sterome, a critical but neglected aspect of fern biology and evolution. Having recently been made a Research Associate at MO, we suspect that the halls of that herbarium will, for years to come, be filled with fern chatter and new discoveries.

Acknowledgments We thank Robbin for sharing his time and knowledge about plants and science with us, for being always available, and for his unstinting generosity. Also, for sharing some of the photographs included in this article, for compiling a very comprehensive manuscript about his early years for us, and for his 
comments and reviews of an earlier version of the manuscript. We are also grateful to Barbara A. Ambrose for inviting us to write this tribute and for discussions and ideas for it. We thank Blanca León and Eddie Watkins for sharing stories and photos of Robbin. A complete list of Robbin's publications is available from him rmoran@nybg.org upon request.

\section{References}

Ambrose, B.A., \& A. Vasco. 2016. Bringing the multicellular fern meristem into focus. New Phytologist 210: 790-793.

Bushey, C.L., \& R.C. Moran. 1978. Vascular flora of Shaw Prairie, Lake County, Illinois. Transactions of the Illinois State Academy of Science 71: 427-435.

Canestraro, B.K., R.C. Moran, \& J.E. Watkins. 2014. Reproductive and physiological ecology of climbing and terrestrial Polybotrya (Dryopteridaceae) at the La Selva Biological Station, Costa Rica International Journal of Plant Sciences 175: 432-441. Available online: https://doi.org/10.1086/675576

Choo, T.Y.S., F.B. Matos, \& R.C. Moran. 2014. The gametophytes and young sporophytes of Elaphoglossum decursivum (Dryopteridaceae) in Costa Rica. American Fern Journal 104: 49-57.

Farrar, D.R. 2002. Obituary: Warren H. Wagner, Jr. (1920-2000). American Fern Journal 92: 39-49. Available online: https://doi.org/10.1640/0002-8444(2002)092[0039:OWHWJ]2.0.CO

Fawcett, S., \& M. Sundue. 2016. Evidence of primary hemiepiphytism in Pleopeltis bradeorum (Polypodiaceae). Brittonia 68: 187-194. Available online: https://doi.org/10.1007/s12228-016-9412-x

Gleason, H.A. 1952. The new Britton and Brown illustrated flora of the northeastern United States and adjacent Canada. New York: N.Y.: Botanical Garden.

Haufler, C.H., K.M. Pryer, E. Schuettpelz, E.B. Sessa, D.R. Farrar, R.C. Moran, J.J. Schneller, J.E.J. Watkins, \& M.D. Windham. 2016. Sex and the single gametophyte: revising the homosporous vascular plant life cycle in light of contemporary research. BioScience 66: 928-937.

Hoshizaki, B.J., \& R.C. Moran. 2001. Fern Grower's Manual. 604 pp. Portland, Oregon: Timber Press.

Kessler, M., R.C. Moran, J.T. Mickel, F.B. Matos, \& A.R. Smith. 2018. Prodromus of a fern flora for Bolivia. XXXV. Dryopteridaceae. Phytotaxa; Vol 353, No 1: 11 June 2018DO - https://doi.org/10.11646/ phytotaxa.353.1.1 353: 1-114. Available online: https://www.biotaxa.org/Phytotaxa/article/view/ phytotaxa.353.1.1

Labiak, P.H., F.B. Matos, G. Rouhan, J.G. Hanks, \& R.C. Moran. 2017. Notes on the Taxonomy and Growth Habits of Three Species of Campyloneurum (Polypodiaceae) from Southeastern Brazil. American Fern Journal 107: 1-20. Available online: https://doi.org/10.1640/0002-8444-107.1.1

Lagomarsino, L.P., A.L. Grusz, \& R.C. Moran. 2012. Primary hemiepiphytism and gametophyte morphology in Elaphoglossum amygdalifolium (Dryopteridaceae). Brittonia 64: 226-235.

Lellinger, D.B. 1989. The ferns and fern-allies of Costa Rica, Panama, and the Chocó. Part 1: Psilotaceae through Dicksoniaceae). Pteridologia No. 2A: 364.

León, B., \& R.C. Moran. 1996. Cyathea concordia (Cyatheaceae), a new pinnate-pinnatifid tree fern from the Peruvian/Ecuadorian border. Brittonia 48: 511-513. Available online: https://doi.org/10.2307/2807869

Li, F.-W., B.C. Tan, V. Buchbender, R.C. Moran, G. Rouhan, C.-N. Wang, \& D. Quandt. 2009. Identifying a mysterious aquatic fern gametophyte. Plant Systematics and Evolution 281: 77-86. Available online: https://doi.org/10.1007/s00606-009-0188-2

Lóriga, J., A.R. Schmidt, R.C. Moran, K. Feldberg, H. Schneider, \& J. Heinrichs. 2014a. The first fossil of a bolbitidoid fern belongs to the early-divergent lineages of Elaphoglossum (Dryopteridaceae). American Journal of Botany 101: 1466-1475. Available online: http://www.amjbot.org/content/early/2014/09/16/ ajb.1400262.abstract

Lóriga, J., A. Vasco, L. Regalado, J. Heinrichs, \& R.C. Moran. 2014b. Phylogeny and classification of the Cuban species of Elaphoglossum (Dryopteridaceae), with description of Elaphoglossum sect. Wrightiana sect. nov. Plant Systematics and Evolution 300: 937-951.

Matos, F.B., J. Prado, \& R.C. Moran. 2015. (042-043) Proposal to modify Article 9 Note 1 and the glossary of the Melbourne Code. Taxon 64: 649.

Matos, F.B., A. Vasco, \& R.C. Moran. 2018. Elaphoglossum doanense and Elaphoglossum tonduzii: new members of Elaphoglossum Sect. Squamipedia (Dryopteridaceae) and their significance for inferring the evolution of rhizome habit and nest-forming leaves within the genus. International Journal of Plant Sciences 179: 296-313. 
Matos, F.B., P.H. Labiak, \& R.C. Moran. 2019. The Decursivum Group of Elaphoglossum sect. Polytrichia (Dryopteridaceae): Nonsubulate Species Nested in an Otherwise Subulatescaled Clade. Annals of the Missouri Botanical Garden 104: 400-428. Available online: https://doi.org/10.3417/2019371

Matos, F.B., J. Lóriga, \& R.C. Moran. In press. Monograph of Elaphoglossum sect. Polytrichia subsect. Apoda (Dryopteridaceae). Systematic Botany 46(3): xx-xx.

Miller, J.S., \& A. Vasco. 2012. Robbin Moran - Recipient of the 2011 Peter Raven Award. Systematic Botany 37: 5-6. Available online: https://doi.org/10.1600/036364412X616567

Moran, R.C. 1978a. Vascular flora of the ravines along Lake Michigan in Lake County, Illinois. Michigan Botanist 17: 120-140.

Moran, R.C. 1978b. Presettlement vegetation of Lake County, Illinois. Pp. 12-18. In: R.Q. Landers \& D.C. Glenn-Lewin (eds.). Proceedings of the 5th Midwest Prairie Conference, Ames, Iowa.

Moran, R.C. 1980. Lake Michigan's ravines along Chicago's north shore. Field Museum Bulletin 51: 8-11.

Moran, R.C. 1981. × Asplenosorus shawneensis, a new natural fern hybrid between Asplenium trichomanes and Camptosorus rhizophyllus. American Fern Journal 71: 85-89. Available online: http://www.jstor.org/ stable/1546733

Moran, R.C. 1987a. Monograph of the neotropical fern genus Polybotrya (Dryopteridaceae). Illinois Natural History Survey Bulletin 34: 1-138.

Moran, R.C. 1987b. Olfersia and Polybotrya. A.R. Smith (ed.). Checklist of Venezuelan Pteridophytes. University of Califormia: Berkley,

Moran, R.C. 1990a. Two new species of Cnemidaria (Cyatheaceae) from Panama. Annals of the Missouri Botanical Garden 77: 246-248. Available online: http://www.jstor.org/stable/2399538

Moran, R.C. 1990b. Three new species of ferns from Mesoamerica. Annals of the Missouri Botanical Garden 77: 591-593. Available online: http://www.jstor.org/stable/2399525

Moran, R.C. 1990c. A new species of Polypodium (Polypodiaceae) and two new species of Hypolepsis (Dennstaedtiaceae) from Mesoamerica. Annals of the Missouri Botanical Garden 77: 845-850. Available online: http://www.jstor.org/stable/2399676

Moran, R.C. 1991a. Eight new species of tree ferns (Cyathea, Cyatheaceae) from the American tropics and three new combinations. Novon 1: 88-104. Available online: http://www.jstor.org/stable/3391634

Moran, R.C. 1991b. Monograph of the Neotropical fern genus Stigmatopteris (Dryopteridaceae). Annals of the Missouri Botanical Garden 78: 857-914.

Moran, R.C. 1991c. Olfersia, Polybotrya, and Stigmatopteris. Pp. 42-47, 57-65. In: R.M. Tryon \& R.G. Stolze (eds.). Pteridophyta of Peru, Fieldiana, Botany, new series, no. 27. Field Museum of Natural History: Chicago,.

Moran, R.C. 1992. Five new species of ferns from the American Tropics. Novon 2: 132-138. Available online: http://www.jstor.org/stable/3391674

Moran, R.C. 1993. Olfersia, Polybotrya, and Stigmatopteris. A.R.A. Görts-van Rijn (ed.). The Flora of the Guianas, Series B: Ferns and Fern allies. Fascicle 6. Dryopteridaceae.

Moran, R.C. 1995. Five new species and two new combinations of ferns (Polypodiopsida) from Ecuador. Nordic Journal of Botany 15: 49-58. Available online: https://doi.org/10.1111/j.1756-1051.1995. tb00120.x

Moran, R.C. 2000. Monograph of the neotropical species of Lomariopsis (Lomariopsidaceae). Brittonia 52: 55-111. Available online: http://link.springer.com/article/10.2307/2666495

Moran, R.C. 2004. A natural history of ferns. 301 pp. Portland, Oregon: Timber Press.

Moran, R.C. 2015. Oliver Sacks (1933-2015), a remembrance. Fiddlehead Forum 42: 5-7.

Moran, R.C., \& P. Labiak. 2009. Megalastrum (Dryopteridaceae) in southeastern Brazil, Paraguay, and Uruguay. American Fern Journal 94: 1-44.

Moran, R.C., \& P.H. Labiak. 2016. Phylogeny and character evolution of the Neotropical fern genus Stigmatopteris (Dryopteridaceae). Brittonia 68: 476-488. Available online: https://doi.org/10.1007/ s12228-016-9437-1

Moran, R.C., \& B. Øllgaard. 1995. Six new species of ferns (Polypodiopsida) from Ecuador. Nordic Journal of Botany 15: 177-185. Available online: https://doi.org/10.1111/j.1756-1051.1995.tb00138.x

Moran, R.C., \& B. Øllgaard. 1998. New species of ferns (Polypodiopsida) from Ecuador. Nordic Journal of Botany 18: 431-439. Available online: https://doi.org/10.1111/j.1756-1051.1998.tb01520.x

Moran, R.C., \& J. Prado. 2010. Megalastrum (Dryopteridaceae) in Central America. Kew Bulletin 65: 137188.

Moran, R.C., \& R. Riba. 1995. Flora Mesoamericana. Volumen 1. Pteridofitas, Psilotaceae a Salviniaceae. (G. Davidse \& M. S. S., Eds.)Flora Mesoamericana (Vol. Volumen 1). Univ. Nacional Autónoma de México, Ciudad Universitaria. [available on the web: http:/www.mobot.org/mobot/fm/ ]. 
Moran, R.C., \& R.V. Russell. 2004. The Occurrence of Trichomanes godmanii (Hymenophyllaceae) on Welfia georgii (Arecaceae) at the La Selva Biological Station, Costa Rica. American Fern Journal 94: 7076. Available online: http://www.jstor.org/stable/1547797

Moran, R.C., \& J.E. Watkins. 2002. The occurrence and morphology of Adiantum Xvariopinnatum (Pteridaceae). Brittonia 54: 57-60. Available online: http://www.jstor.org/stable/3218487

Moran, R.C., \& J.E. Watkins. 2004. Lomariopsis $\times$ farrarii: a new hybrid fern between L. japurensis and L. vestita (Lomariopsidaceae) from Costa Rica. Brittonia 56: 205-209. Available online: https://doi.org/10. 1663/0007-196X(2004)056[0205:LFANHF]2.0.CO

Moran, R.C., S. Klimas, \& M. Carlsen. 2003. Low-Trunk Epiphytic Ferns on Tree Ferns Versus Angiosperms in Costa Rica. Biotropica 35: 48-56. Available online: http://www.jstor.org/stable/30043033

Moran, R.C., J.G.G. Hanks, \& G. Rouhan. 2007. Spore morphology in relation to phylogeny in the fern genus Elaphoglossum (Dryopteridaceae). International Journal of Plant Sciences 168: 905-929. Available online: http://www.jstor.org/stable/10.1086/518269

Moran, R.C., J. Prado, \& P.H. Labiak. 2009. Megalastrum (Dryopteridaceae) in the West Indies. Brittonia 61: 273-292.

Moran, R.C., J.G. Hanks, P. Labiak, \& M. Sundue. 2010. Perispore morphology of bolbitidoid ferns (Dryopteridaceae) in relation to phylogeny. International Journal of Plant Sciences 171: 872-881. Available online: http://www.jstor.org/stable/info/10.1086/655856

Moran, R.C., P.H. Labiak, \& M. Sundue. 2010a. Synopsis of Mickelia, a newly recognized genus of bolbitidoid ferns (Dryopteridaceae) 62: 337-356.

Moran, R.C., P.H. Labiak, \& M. Sundue. 2010b. Phylogeny and character evolution of the bolbitidoid ferns (Dryopteridaceae). International Journal of Plant Sciences 171: 547-559. Available online: http://www. jstor.org/stable/10.1086/652191

Moran, R.C., J. Prado, \& M.A. Sundue. 2014a. Megalastrum (Dryopteridaceae) in Andean South America, Part I. American Fern Journal 104: 109-178. Available online: https://doi.org/10.1640/0002-8444-104.3. 109

Moran, R.C., J. Prado, \& M.A. Sundue. 2014b. Megalastrum (Dryopteridaceae) in Andean South America, Part II. American Fern Journal 104: 181-236.

Moran, R.C., J.G. Hanks, \& P.H. Labiak. 2018. Evolution of Spore Morphology in the Blechnaceae. International Journal of Plant Sciences 179: 712-729. Available online: https://doi.org/10.1086/699798

Moran, R.C., J. Prado, R. Hirai, \& F.B. Matos. 2020. (022) Proposal to modify Article 60.8(a). Taxon 69: 636. Available online: https://doi.org/10.1002/tax.12260

Murakami, N., \& R.C. Moran. 1993. Monograph of the neotropical species of Asplenium sect. Hymenasplenium (Aspleniaceae). Annals of the Missouri Botanical Garden 80: 1-38.

Nitta, J.H., \& M.J. Epps. 2009. Hemi-epiphytism in Vandenboschia collariata (Hymenophyllaceae). Brittonia 61: 392. Available online: https://doi.org/10.1007/s12228-009-9097-5

Pacheco, L., \& R.C. Moran. 1999. Monograph of the neotropical species of Callipteris with anastomosing veins (Woodsiaceae). Brittonia 51: 343-388.

Prado, J., \& R.C. Moran. 2008. Revision of the neotropical species of Triplophyllum (Tectariaceae). Brittonia 60: $103-130$.

Prado, J., \& R.C. Moran. 2010. (088) Proposal to modify Recommendation 9A.4 of the Vienna Code. Taxon 59: 306-307.

Prado, J., \& R.C. Moran. 2014. (018-020) Proposals to amend Articles 9.1, 9.2, 9.11, and the glossary of the Melbourne Code. Taxon 63: 448.

Prado, J., \& R.C. Moran. 2016. Monograph of the West Indian fern genus Polystichopsis (Dryopteridaceae). Brittonia 68: 1-24. Available online: https://doi.org/10.1007/s12228-015-9387-z

Prado, J., K.N. Ganhdi, M. Sundue, \& R.C. Moran. 2010. (083) Proposal to include the terms "Isolectotype", "Isoneotype", and "Isoepitype" in the Code. Taxon 59: 304.

Prado, J., R.Y. Hirai, \& R.C. Moran. 2015. (046-048) Proposals concerning inadvertent lectotypifications (and neotypifications). Taxon 64: 651.

Prado, J., R.Y. Hirai, \& R.C. Moran. 2020. (010) Proposal to add a new Note and a new Example after Article 9.6. Taxon 69: 629. Available online: https://doi.org/10.1002/tax.12250

Rouhan, G., \& R.C. Moran. 2011. Monograph of the paleotropical species of Megalastrum (Dryopteridaceae). Annals of the Missouri Botanical Garden 98: 90-100.

Rouhan, G., J.-Y.Y. Dubuisson, F. Rakotondrainibe, T.J. Motley, J.T. Mickel, J.-N.N. Labat, \& R.C. Moran. 2004. Molecular phylogeny of the fern genus Elaphoglossum (Elaphoglossaceae) based on chloroplast non-coding DNA sequences: contributions of species from the Indian Ocean area. Molecular Phylogenetics and Evolution 33: 745-763.

Sacks, O. 2002. Oaxaca Journal. 176 pp. Washington, DC: Vintage Books. 
Skog, J.E., J.T. Mickel, R.C. Moran, E.A. Zimmer, \& M. Volovsek. 2004. Molecular studies of representative species in the fern genus Elaphoglossum (Dryopteridaceae) based on cpDNA sequences rbcL, trnL-F, and rps4-trnS. International Journal of Plant Sciences 165: 1063-1075.

Smith, A.R. 1981. Flora of Chiapas, Part 2. Pteridophytes. 370 pp. (D. E. Breedlove, Ed.). San Francisco, California: The California Academy of Sciences.

Stolze, R.G. 1976. Ferns and fern allies of Guatemala, Part I: Ophioglossaceae through Cyatheaceae. 130 pp. Chicago: Field Museum of Natural History.

Stolze, R.G. 1981. Ferns and fern allies of Guatemala, Part II: Polypodiaceae. 522 pp. Chicago: Field Museum of Natural History.

Stolze, R.G. 1983. Ferns and fern allies of Guatemala, Part III. 91 pp. Chicago: Field Museum of Natural History.

Sundue, M., G. Rouhan, \& R.C. Moran. 2010. Megalastrum (Dryopteridaceae) of the circumaustral region: Chile, Argentina, and southern islands of the Atlantic, Pacific, and Indian Oceans. Systematic Botany 35 : 461-475.

Sundue, M., A. Vasco, \& R.C. Moran. 2011. Cryptochlorophyllous Spores in Ferns: Nongreen Spores that Contain Chlorophyll. International Journal of Plant Sciences 172: 1110-1119.

Testo, W., \& M. Sundue. 2014. Primary hemiepiphytism in Colysis ampla (Polypodiaceae) provides new insight into the evolution of growth habit in ferns. International Journal of Plant Sciences 175: 526-536. Available online: http://www.jstor.org/stable/10.1086/675934

Tuomisto, H., \& R.C. Moran. 2001. Marattiaceae. Flora of Ecuador 66: 23-68.

Tuomisto, H., A.D. Poulsen, \& R.C. Moran. 1998. Edaphic Distribution of Some Species of the Fern Genus Adiantum in Western Amazonia1. Biotropica 30: 392-399. Available online: https://doi.org/10.1111/j. 1744-7429.1998.tb00073.x

Tuomisto, H., K. Ruokolainen, A.D. Poulsen, R.C. Moran, C. Quintana, G. Cañas, \& J. Celi. 2002. Distribution and diversity of pteridophytes and Melastomataceae along edaphic gradients in Yasuní National Park, Ecuadorian Amazonia. Biotropica 34: 516-533. Available online: https://doi.org/10. 1111/j.1744-7429.2002.tb00571.x

Tuomisto, H., A.D. Poulsen, K. Ruokolainen, R.C. Moran, C. Quintana, J. Celi, \& G. Cañas. 2003. Linking floristic patterns with soil heterogeneity and satellite imagery in Ecuadorian Amazonia. Ecological Applications 13: 352-371. Available online: https://doi.org/10.1890/1051-0761(2003)013[0352: LFPWSH]2.0.CO

Vasco, A., \& B.A. Ambrose. 2020. Simple and Divided Leaves in Ferns: Exploring the Genetic Basis for Leaf Morphology Differences in the Genus Elaphoglossum (Dryopteridaceae). International Journal of Molecular Sciences .

Vasco, A., R.C. Moran, \& G. Rouhan. 2009. Monograph of the Elaphoglossum ciliatum group (Dryopteridaceae). Brittonia 61: 241-272.

Vasco, A., J.T. Mickel, \& R.C. Moran. 2013a. Taxonomic revision of the neotropical species of Elaphoglossum Sect. Squamipedia (Dryopteridaceae). Annals of the Missouri Botanical Garden 99: $244-286$.

Vasco, A., R.C. Moran, \& B.A. Ambrose. 2013b. The evolution, morphology, and development of fern leaves. Frontiers in plant science 4: 345 .

Vasco, A., J. Lóriga, G. Rouhan, B.A. Ambrose, \& R.C. Moran. 2015. Divided leaves in the genus Elaphoglossum (Dryopteridaceae): A phylogeny of Elaphoglossum section Squamipedia. Systematic Botany 40: 46-55. Available online: http://www.bioone.org/doi/abs/10.1600/036364415X686323

Vasco, A., T.L. Smalls, S.W. Graham, E.D. Cooper, G.K.-S. Wong, D.W. Stevenson, R.C. Moran, \& B.A. Ambrose. 2016. Challenging the paradigms of leaf evolution: Class III HD-Zips in ferns and lycophytes. The New phytologist 212: 745-758. Available online: http://www.ncbi.nlm.nih.gov/pubmed/27385116

Watkins, J.E., \& R.C. Moran. 2019. Gametophytes of the Fern Genera Dracoglossum and Lomariopsis (Lomariopsidaceae) and their Phylogenetic Significance. International Journal of Plant Sciences 180: 1004-1015. Available online: https://doi.org/10.1086/705587

Watts, J.L., R.C. Moran, \& J.E. Watkins. 2019. Hymenasplenium volubile: documentation of its gametophytes and the first record of a hemiepiphyte in the Aspleniaceae. Annals of Botany 124: 829-835. Available online: https://doi.org/10.1093/aob/mcz124 